\title{
De la eclosión a la consolidación. Una mirada aproximativa a la construcción de lo popular por el nuevo cine chileno 1258 - $1970^{\prime}$
}

\author{
$(\mathrm{O})$ \\ Juan Pablo Silva Escobar* \\ Recibido: 3 de septiembre de 2008 \\ Aprobado: 6 de octubre de 2008
}

\section{Resumen}

Este artículo se desarrolla a partir de la idea de que la práctica cinematográfica desarrollada por el Nuevo Cine Chileno se configura como una práctica significante que permite, a través de la producción fílmica, dar cuenta del proceso de construcción de una nueva concepción acerca de lo popular. Así, esta concepción ubica en el centro de sus preocupaciones los conflictos socioculturales, políticos y económicos, configurando lo popular como un estilo de vida y como una clase social que se encuentra en tensión continua con la clase dominante. Esta tensión nos lleva a tener presente que las formas y actividades culturales son un campo dinámico, en el cual se articulan relaciones de dominación y subordinación. Concentrarnos en los procesos por los cuales determinadas relaciones de poder se instalan dentro del campo cultural, nos permite dar cuenta de las cambiantes y desiguales relaciones de fuerza, poniendo atención a la relación entre la cultura y las cuestiones de hegemonía. Así, lo que propongo es discutir desde y sobre las implicancias ideológicas inscritas en la práctica cinematográfica desarrollada por el Nuevo Cine Chileno.

\section{Palabras clave}

Ideología, nuevo cine chileno, popular, poder simbólico.

* Antropólogo y Magíster (c) en Estudios Latinoamericanos

Institución: Centro de Estudios Culturales Latinoamericanos (CECLA), Universidad de Chile, E-mail: jupase@vtr.net 


\title{
From uprising to consolidation. An approach to the construction of what is popular by the New Chilean Cinema, 1958-1970
}

\begin{abstract}
This article has been developed from the idea that cinematographic practice developed by the New Chilean Cinema has been configured as a meaningful practice which allows, through film production, accounting for the construction process of a new conception about what is popular. Therefore, this conception focuses on socio-cultural, political, and economic conflicts, thus configuring what is popular as a lifestyle and as a social class which is within a permanent tension with dominant class. This tension makes us bear in mind that cultural ways and activities are a dynamic field in which domination and subordination relationships join. Focusing on processes by which some power relationships settle within the cultural field allows us to account for changing and unequal relationships of power, paying attention to the relationship between culture and hegemony matters. Then, what I propose is to discuss from and about ideological implications resulting from the cinematographic practice developed by the New Chilean Cinema.
\end{abstract}

\section{Key words}

Ideology, new chilean cinema, popular, symbolic power. 
El cine no presenta solamente imágenes, las rodea de un mundo. Gilles Deleuze

Desde un punto de vista cultural, el cine objetiva, refleja y amplifica en imágenes y sonidos las creencias y valores dominantes, emergentes o residuales. El cine objetiva, porque crea unas materialidades visuales para aquello que en el imaginario era sólo escritura, noción o abstracción. El cine refleja, porque tiene como punto de partida el material disponible en el imaginario de la época de su realización. El cine amplifica el imaginario, porque lo instala en el dominio colectivo, en las diferentes audiencias a las que está dirigido. De ahí que conceptualmente el cine será comprendido como una práctica significante, entendiendo que la práctica cinematográfica se constituye en parte integrante de la cultura de la cual procede.

Este trabajo se desarrolla desde el supuesto de que las prácticas culturales pueden responder a estilos de vida dominantes, emergentes o residuales, pero cuyos contenidos están enteramente determinados por los contextos históricos de su aparición. Por residual se entiende algo diferente de lo arcaico. Lo residual ha sido formado en el pasado pero continúa en actividad en el proceso cultural, no sólo como un elemento del pasado, sino también como un efectivo elemento del presente que se encuentra a cierta distancia de la cultura dominante y que eventualmente será incorporado o destruido por esta (Williams, 1980, p. 144-145). Por emergente se entenderán aquellas nuevas prácticas, nuevos significados y valores, nuevas relaciones y tipos de relaciones que se crean continuamente. (Ibíd. 1980, p. 145). Desde el momento en que pretendemos considerar las relaciones dentro de un proceso cultural, lo residual y lo emergente sólo pueden originarse en su relación con lo dominante. Asimismo, un orden dominante nunca incluye toda la práctica humana; siempre deja intersticios para que surjan elementos residuales o emergentes.

El trabajo se articula a partir de la idea de que la práctica cinematográfica desarrollada por el nuevo cine chileno se configura como una práctica significante que permite, a través de la producción fílmica, dar cuenta del proceso de construcción de una nueva concepción acerca de lo popular. Así, esta concepción ubica en el centro de sus preocupaciones los conflictos socioculturales, políticos y económicos, configurando lo popular como un estilo de vida y como una clase social que se encuentra en tensión continua con la clase dominante. Esta tensión nos lleva a tener presente que las formas y actividades culturales son un campo dinámico, en el cual se articulan relaciones de dominación y subordinación. Concentrarnos en los procesos por los cuales determinadas relaciones de poder se instalan dentro del campo cultural nos permite dar cuenta de las cambiantes y desiguales relaciones de fuerza, poniendo atención a la relación entre la cultura y las cuestiones de hegemonía.

Hasta antes del surgimiento del nuevo cine chileno, los sujetos populares no eran más que un recurso dramático dentro del argumento de un relato cinematográfico. En última instancia, esta sección de la población era proyectada en la pantalla como el reverso de una sociedad que históricamente ha excluido a las clases populares. De este modo, el cine ratificaba el insistente ejercicio de «blanqueamiento» que han adoptado las elites desde la colonia en 
adelante, negándoles a los sujetos populares la categoría de sujetos sociales, construyéndolos a partir del estereotipo, de lo exótico, presentándonos sujetos deificados y subordinados. Lo popular, para ese tipo de cinematografía, era entonces el borracho, la prostituta, el abusador de mujeres o el sujeto que nos hace reír mediante la humillación. Es este un sujeto sin historicidad e inconsciente de su condición social y, por lo tanto, desclasado y despolitizado. Frente a este estado de cosas, existe cierto consenso en que el gran mérito del nuevo cine chileno fue el de proyectar una cierta diversidad de las prácticas culturales y las problemáticas sociales y económicas ligadas a los sectores populares.

La hipótesis plantea que la práctica cinematográfica desarrollada por el Nuevo cine chileno, a la par con otras manifestaciones artísticas (pintura, fotografía, literatura, teatro), vienen a construir y reconstruir nuevas representaciones acerca de los conflictos sociales, de lo popular y de lo que en su momento se llamó «hombre nuevo». Representaciones que no son ni neutras ni transparentes, más bien actúan bajo un propósito, de acuerdo con una tendencia y en un ambiente histórico, intelectual e incluso económico. En otras palabras,

«las representaciones tienen sus fines, son efectivas la mayoría de las veces y consiguen uno o más de sus objetivos, las representaciones son formaciones y deformaciones) (Said 1990, p. 32).

De ahí que en la construcción cinematográfica de ese «hombre nuevo» y de sus problemáticas sociales, culturales, políticas y económicas, se objetiva en imágenes y sonidos un momento histórico, cultural, social, estético e ideológico que se inscribe dentro de lo que Foucault ha llamada las mallas del poder, entendiendo que

una sociedad no es un cuerpo unitario en el que se ejerza un poder y solamente uno, sino que en realidad es una yuxtaposición, un enlace, una coordinación y también una jerarquía de diferentes poderes (Foucault 1999, p. 239).

Por ello, sostengo que la especificidad del nuevo cine chileno fue la de constituirse como una producción simbólica que se expresa a través de metáforas, metonimias y sinécdoques, y que articula una simbólica del poder no sólo a través de la elaboración de la percepción de lo real sino, además, segregando los imaginarios.

En líneas generales, el nuevo cine chileno se enmarca dentro de lo que se ha signado como nuevo cine latinoamericano. Estos «nuevos cines» a escala continental eclosionan en un momento histórico particular. Con el fin de la Segunda Guerra Mundial y el inicio de la Guerra Fría se configuró un nuevo orden mundial que polarizó las opciones políticas e incrementó la intervención y el imperialismo norteamericano en América Latina. Con distintas estrategias, desde los Cuerpos de Paz hasta la imposición por la fuerza de gobiernos títere, Estados Unidos impulsó un modelo de desarrollo capitalista en el que la industrialización y la modernización del Estado armonizaban con los intereses de las oligarquías nacionales, directamente ligadas al proceso económico occidental en manos de las grandes empresas multinacionales. En este contex- 
to, muchos intelectuales se acercaron a las posiciones de izquierda y simpatizaron con el triunfo de la Revolución Cubana:

Le otorgará al marxismo un nuevo prestigio entre los intelectuales latinoamericanos y un optimismo frente al nuevo sujeto de la representación: el pueblo como masa trabajadora y desde este punto de vista el proyecto político y cultural de la revolución cubana coincidió con la actitud revolucionaria de importantes sectores latinoamericanos (Alegría 1986, p. 370).

Históricamente, el surgimiento del nuevo cine latinoamericano se vincula directamente con la revolución cubana, la Tercera Vía peronista en Argentina y la Unidad Popular en Chile, y se concreta en movimientos cinematográficos como el Cinema Novo brasileño, el Cine de Liberación en Argentina y el Instituto Cubano de Arte e Industria Cinematográficos (ICAIC). Desde una perspectiva estética, el movimiento se inspiró en tendencias tan diversas como el montaje soviético, el surrealismo, el neorrealismo italiano, el teatro épico brechtiano, el cinèma vèrité y la nouvelle vague francesa. En cuanto al plano político, los cineastas latinoamericanos del Nuevo Cine consiguieron distinguirse de los realizadores europeos principalmente porque se encontraban más comprometidos con la lucha revolucionaria que sus colegas del Viejo Mundo. La dimensión marcadamente política se encuentra reflejada tanto en las obras como en los diversos manifiestos que «valoraban un cine alternativo, independiente, antiimperialista, más preocupado por ser provocador y combativo que con la expresión de autor o la satisfacción del consumidons (Shohat y Stam 2002, p. 250) Tanto en las obras como en los manifiestos, los cineastas no sólo se desmarcan del llamado primer y segundo cine, sino también de las tradiciones comerciales de sus propios países que eran vistas como burguesas, alienadas y colonizadas.

\section{LA ECLOSIÓN DE UNA NUEVA PRÁCTICA CINEMATOGRÁFICA}

En Chile, la génesis de una nueva práctica cinematográfica se inicia a mediados de los años 50, bajo el alero de la Universidad Católica y de la Universidad de Chile. En 1955, Rafael Sánchez funda el Instituto Fílmico de la Universidad Católica, iniciando en el país la enseñanza del cine en el nivel superior (Vega, 2006, p. 163). Sánchez es un sacerdote jesuita, que en 1958 realiza el documental Las callampas, un encargo realizado por el Hogar de $\mathrm{Cristo}^{2}$.En líneas generales la película registra la toma de terrenos de La Feria, pertenecientes al gobierno, donde luego se dará origen a la mítica población La Victoria. Estructurada en forma de reportaje, mostrando la ocupación y las reacciones inmediatas, la película intenta ser un reflejo «objetivo» de una toma de terrenos. Si bien es cierto que hay una preocupación especial por revelar las condiciones de extrema pobreza de los pobladores a través del retrato de acciones como el loteo, las ollas comunes, la instalación de sanitarios provisorios, el armado de carpas con palos y frazadas (con banderitas chilenas en lo alto de cada una de ellas); la película no intenta explicar las causas de dichas acciones, se limita tan sólo a describirlas. 
En la Universidad de Chile, a mediados de los 50, un grupo de estudiantes conformó un cine-club, una revista cinematográfica, un programa radial y la proyección semanal de películas europeas, buscando así consolidar una alternativa al cine hollywoodense y a la Época de Oro del cine latinoamericano. ${ }^{3}$ Fue a partir de estas actividades cuando se generó el deseo por participar activamente en la producción fílmica, dando paso a la fundación, en 1959, del Centro de Cine Experimental de la Universidad de Chile que tiene como sus principales objetivos: (1) La investigación de los medios audiovisuales en busca de un lenguaje propio de trabajo; 2) la formación de profesionales; y 3) la producción de películas para uso universitario» (Mouesca 1988, p. 16). Más tarde estos objetivos serán ampliados y redefinidos.

Desde sus comienzos el Centro de Cine Experimental, inspirado por el neorrealismo italiano, se concentró en realizar documentales acerca de lo popular. Ejemplo de esto es el documental de Sergio Bravo Día de organillos (1959), que muestra a los organilleros desplazándose por los distintos barrios de Santiago y tocando su instrumento. El documental muestra cómo estos personajes acondicionan y cargan en sus espaldas los pesados instrumentos, buscando producir un contraste entre las carencias socioeconómicas de éstos sujetos populares y la opulencia de la clase dominante que los observa desde sus cómodas viviendas. En 1960 se realiza el documental Marcha de los obreros del carbón, bajo la dirección de Sergio Bravo, que narra la protesta de los obreros de la Compañía Carbonífera e Industrial de Lota que mar- charon 40 kilómetros entre Lota y Concepción acompañados por sus familiares y adherentes. Al respecto Bravo comenta:

La marcha, como se recordará, fue un dramático acontecimiento sindical y político. Fue organizada para quebrar la resistencia de la compañía, que se negaba a facilitar una solución a una huelga que se prolongaba ya durante tres meses. Aunque la población de la zona, incluidos los comerciantes y los feriantes, ayudaba a mantener las ollas comunes, la situación se tornaba cada día más difícil, porque había que alimentar a mucha gente. Así que los sindicatos decidieron marchar desde Lota a Concepción, que están a $40 \mathrm{~km}$ de distancia. Alrededor de cincuenta mil personas, los mineros con sus mujeres y sus niños. Una marcha histórica, en un día luminoso, con un viento que hacía flamear las miles de banderas. Todo se prestaba para hacer un buen documental (Bravo citado en Muesca 1988, p. 19).

Así, estamos en presencia de los inicios de una nueva concepción cinematográfica, que se sustenta a partir de la incorporación a su discurso audiovisual de las problemáticas socioeconómicas que afectan a los sectores populares. Un ejemplo de esto lo encontramos en el trabajo de Patricio Kaulen Un hogar sin tierra (1961), el cual denuncia la carencia habitacional de un grupo de personas de bajos recursos, mostrando los problemas del hacinamiento familiar. Sin embargo, esta etapa inicial, que podemos denominar como de eclosión, se va a carac- 
terizar principalmente por rescatar prácticas culturales ligadas a lo popular como la tradición campesina (Trilla (1958) de Sergio Bravo, Rodeo de Parral (1960) de Dagoberto Escárate, Pomaire (1960) de Juan Pérez) o vinculados a la cuestión de la religiosidad popular, como Andacollo (1958) de Jorge di Lauro y Nieves Yankovic

En 1962 se produce la visita al país de Joris Ivens - un documentalista social de larga trayectoria- invitado por el Centro de Cine Experimental de la Universidad de Chile. Ivens realiza una serie de charlas y cursos de perfeccionamiento, y propone realizar una experiencia práctica. Se elige como tema la ciudad de Valparaíso y en noviembre de 1962 se comienza con el rodaje de A Valparaíso, que será estrenada en septiembre de 1964. En 1962, también visita el país Edgar Morin, quien realiza en conjunto con Patricio Guzmán y Pedro Chaskel el documental Alameda. Aprovechando la visita del sociólogo francés se proyecta en la biblioteca Nacional Chronique d'un été, documental realizado junto a Jean Rouch, uno de los fundadores del Cinèma vèrité.

En cuanto al cine de ficción, muchos investigadores han calificado al decenio de los años 50 como perdido. Sin embargo, la pelí cula Tres miradas a la calle (1957), de Naum Kramarenko, puede considerarse una primera aproximación a la representación, aunque superficial, del entorno social chileno. La película se estructura a partir de tres historias que relatan las fricciones entre las condiciones sociales y la vida individual y familiar. En la primera historia, María, encontramos la influencia del neorrealismo italiano; las dos siguientes, Cosas de Arica y
Ojos de gato, siguen la influencia del Free Cinema británico, donde la ironía, en tanto tropo retórico, es lo que sostiene el relato. Así, en esta película encontramos las primeras aproximaciones de lo que, en el transcurso de los años 60, se desarrollará como una nueva opción cinematográfica. Ya en 1960 Hernán Correa, realiza Un viaje a Santiago, película que relata el viaje de los vecinos de Tunco para hablar con el diputado Beroa, quien les prometió durante la campaña electoral reparar el camino que los mantiene aislados. La película construye una mirada idealizada de las relaciones sociales rurales en oposición con la ciudad que se constituye como un espacio de poder y dominación. En 1961 Naum Kramarenko lleva a la pantalla Deja que los perros ladren, una adaptación de una exitosa obra teatral de los años 50 de Sergio Vodanovic. La película se construye como un drama de interiores que tiene como eje un matrimonio y su hijo de 20 años. La película busca dar cuenta de la corrupción gubernamental en concomitancia con un periódico. En 1964 Aldo Francia realiza La escala, un cortometraje que muestra la vida de la escalera del cerro Larraín de Valparaíso. La historia se desarrolla de manera simple, gente que sube y baja por la escalera, un organillero que toca su instrumento y observa, un grupo de niños que juegan a las canicas y cuando terminan de jugar se les queda una olvidada. Desafortunadamente, pasa por allí una pareja con su bebé, la madre tropieza con la canica y el bebé muere. Esta simplísima historia, aparte de haber sido la primera película rodada en color en el país, constituye una búsqueda de una nueva cinematografía que pretende incorporar tendencias neorrealista mezclándolas con una estructura surrealista. 
En este primer momento, la relación significativa entre la eclosión de una nueva práctica cinematográfica y el contexto histórico se vuelve significante. Si analizamos la elección de 1958, vemos que la coalición de derecha encabezada por Jorge Alessandri Rodríguez e integrada por conservadores, liberales y radicales, gana las elecciones presidenciales con un 31,6\% de los votos, seguido por Salvador Allende Gossens candidato del Frente de Acción Popular Unitario (FRAP) que obtuvo el $28,9 \%$ de los votos y, en tercer lugar, con el 20,7\% el abanderado del recién formado Partido Demócrata Cristiano (PDC), Eduardo Frei Montalva.

Una primera mirada a estas votaciones nos habla de la estrechez del triunfo de Alessandri y nos da cuenta de la popularidad que comenzaban a experimentar las alternativas reformistas que proponían cambios en los órdenes político, social y económico. Esta sería la última elección democrática en que la derecha saldría triunfadora. La estrechez del triunfo de la derecha y el clima de reforma social que imperaba en gran parte de América Latina, impulsado principalmente por el triunfo de la revolución cubana, trajo consigo que el gobierno de Alessandri se apartara de los programas clásicos de la derecha e intentara realizar un gobierno con una leve inclinación hacia proyectos de mayor protección social e incluso se esbozó una incipiente reforma agraria, aunque con resultados modestísimos.

Por otra parte, en la década de los 50 se produce la caída de la «estructura política que había gobernado desde la década de los 30» (Jocelyn-Holt, 1999, p. 91). Paralelamente a la desestructuración de un modelo político basado en la construcción de un «orden nacional» llevado adelante por una oligarquía terrateniente y una burguesía industrial e importadora; habría que agregar la emergencia de una creciente sociedad de masas que surgía debido a la explosión migratoria del campo a la ciudad, produciendo un crecimiento poblacional urbano que se concentra, principalmente, en Santiago.

Más aún, dicha masificación se vería agravada por el estancamiento del modelo de sustitución de importaciones que se venía imponiendo desde los 40 (Ibíd. 1999, p. 91).

De ahí, en parte, que la década de los 50 estuviera marcada por continuas manifestaciones sociales que daban cuenta de un creciente conflicto social, marcado por una espiral inflacionaria que trajo consigo manifestaciones, huelgas y demandas sociales que no solamente remecieron el orden político, sino que también repercutieron en las diversas expresiones artísticas. Es dentro de este contexto sociopolítico donde se comienza a forjar una nueva concepción de producción fílmica, que se concentra básicamente en describir, narrar y representar a las clases populares con una mirada que se realiza desde la delación de ciertas condiciones sociales, pero que no se compromete ni con la lucha ni con el cambio social.

\section{LA CONSOLIDACIÓN DE LO EMERGENTE}

A este primer período de eclosión, le sigue un segundo período que podemos delimitar, un tanto arbitrariamente, entre la elección como presidente de Eduardo Frei Montalva, el 4 de septiembre de 1964, y la elección como presidente de Salvador Allen- 
de Gossens, en 1970. Este segundo período se va a caracterizar por una producción fílmica comprometida políticamente con un proyecto de país que se encamina hacia «la vía chilena al socialismo» y un discurso audiovisual que construye lo popular desde una mirada que lo adscribe a la lucha social. Esta segunda etapa va a estar enmarcada por ciertos hitos cinematográficos y por ciertos contextos históricos en los cuales estos hitos adquieren significación.

Dentro de este período de emergencia y consolidación del nuevo cine chileno, la situación socioeconómica del país da cuenta de una nación pobre. Si en 1960 había 7,37 millones de habitantes, al finalizar la década esa cifra había crecido a 8,88 millones. De esa población, tres tercios vivían en zonas urbanas y un tercio en zonas rurales. Chile era un país pobre atravesado por grandes desigualdades: en 1969, 21\% de la población vivía en la extrema pobreza. En 1960, sólo el 38\% de la población tenía casa propia. Ese mismo año, el 16\% de los mayores de 15 años era analfabeto, sólo el 1,8\% de los estudiantes accedía a la educación universitaria, el $23,9 \%$ a la enseñanza media y el $60 \%$ a la educación primaria.

Durante la década de los 60, la radio era el medio de comunicación masiva más relevante. La gran mayoría de los chilenos se informaba y entretenía a través de las radioemisoras. Al iniciar la década existían más de un millón de receptores y al finalizar los 60 esa cifra se había multiplicado por tres. La televisión se instaló lentamente entre finales de los 50 y comienzos de los 60, asociada a las principales universidades del país, con muy pocas horas de trasmisión al día y una escasa teleaudiencia. Hacia 1964 había sólo 31 mil televisores, así que el cine seguía siendo uno de los espacios preferidos por los chilenos para utilizar el tiempo de ocio. Según algunos cálculos, en 1960 había en Chile unas trescientas salas de exhibición, que eran abastecidas principalmente por la industria hollywoodense y la industria latinoamericana (principalmente de México y Argentina). Debido al alto analfabetismo, esta forma de entretención tenía un fuerte arraigo en la clase popular, principalmente durante las décadas del $40 \mathrm{y}$ del 50 , contribuyendo a la gestación de un poderoso imaginario social.

En 1964, debido al abandono de la carrera presidencial de la coalición de derecha ante la evidencia de un fracaso, se ven enfrentadas las opciones de centro, encabezadas por Eduardo Frei del Partido Demócrata Cristiano (PDC), y la coalición de izquierda encabezada por Salvador Allende. Ambas candidaturas ofrecían al electorado reformas al sistema económico y social, con diferencias evidentes que aquí no compete en comentar. Durante esas elecciones, Sergio Bravo realiza el documental Banderas del Pueblo a partir del material de archivo proporcionado por los noticiarios de cine, de fotografías y de datos sobre la vida política del país desde 1936 hasta las elecciones de 1964. El documental realiza un seguimiento a los diversos actos y manifestaciones de la campaña presidencial de Salvador Allende. Al parecer, el Consejo de Censura Cinematográfico consideró demasiado allendista el documental y terminó por censurarlo.

A partir de la derrota de la coalición de izquierda se generó un amplio debate acerca del rol que deberían jugar los artistas e 
intelectuales de izquierda en la lucha contra la hegemonía y

sobre la necesidad de que los trabajadores culturales sustrajeran los valores del sentido común del control de la derecha o de la Democracia Cristiana (King, 1994, p. 241).

Estos debates y estrategias trajeron consigo un florecimiento de las actividades culturales de izquierda tanto en la música, como en la pintura, el teatro y el cine.

Así, por ejemplo, de las 20 películas de ficción y de los 26 documentales estrenados en Chile entre 1965 y 1969, al menos 14 películas de ficción y 18 de los documentales ubican en el centro de sus preocupaciones a los sujetos populares y sus prácticas socioculturales, ya no como sujetos descentrados, carentes de procesos políticos, sino como sujetos complejos, que se fragmentan en múltiples adscripciones identitarias: de clase, de género, socioculturales, económicas, políticas e ideológicas.

El cortometraje Angelito (1966), de Luis Cornejo, relata los sucesivos despidos de Rosa Órdenes, una empleada doméstica que trabaja en residencias de la alta burguesía capitalina. Rosa pierde sus empleos debido al llanto incontrolable de su hijo de 4 meses durante las noches, llanto que termina por irritar a los patrones quienes optan por despedirla. En esta película encontramos la enunciación de una serie de temas que tienen su anclaje en problemáticas sociales y de género, a saber, la situación de las «madres solteras» y sus «huachos» ${ }^{4}$,en una sociedad altamente conservadora, donde las clases dominantes luchan por un «blanqueamiento» que busca borrar o tachar nuestra condición de mestizos ${ }^{5}$.

Dentro de la variedad de temas que emergen durante este período, encontramos el docudrama Aborto (1965) de Pedro Chaskel. La película nos relata el peregrinaje de una mujer de bajos recursos que recurre a la atención clandestina poblacional para realizarse un aborto. El aborto es mal realizado y la mujer enferma y debe asistir a un centro médico. Allí le salvan la vida y recibe información sobre el uso de anticonceptivos. Esta película fue realizada por encargo de un centro de servicio social que veía en la práctica cine matográfica un medio eficaz en la trasmisión de conocimiento. Así, el cine es percibido por las organizaciones sociales como una herramienta que ayuda a producir y transmitir eficazmente determinados mensajes y, a su vez, los realizadores proponen la práctica cinematográfica como una actividad cultural que participa activamente al servicio de ciertas problemáticas sociales que, por lo general, no encuentran cabida en los medios de comunicación que se encuentran en manos de las clases dominantes.

Los años 1967 a 1970 son considerados como el momento en que los jóvenes cineastas alcanzan la madurez creativa. Es durante este período cuando se realizan una serie de películas que serán consideradas como emblemas para el Nuevo cine chileno: Largo viaje (1967) de Patricio Kaulen; Tres tristes tigres (1968) de Raúl Ruiz; Caliche sangriento (1969) de Helvio Soto; Valparaíso mi amor (1969) de Aldo Francia, El chacal de Nahueltoro (1970) de Miguel Littín. Estas películas no sólo fueron importantísimas para el desarrollo de un cine nacional, sino que 
también han pervivido en el imaginario social, convirtiendo a sus realizadores en verdaderos iconos de la cinematografía nacional, a veces mitificados en exceso como es el caso de Raúl Ruiz. Muchos de los innumerables análisis que se han publicado acerca de estas películas se remiten a señalar que es en este período cuando es posible determinar la existencia de un grupo de cineastas que podían verse como una unidad; sin embargo, es pertinente señalar la existencia de tendencias ideológicas y estéticas disímiles entre sí.

A pesar de lo anterior, efectivamente la cinematografía de este período puede considerarse como un movimiento por cuanto, tanto los cineastas como sus obras, comparten ciertas particularidades y motivaciones. Una característica en común es el hecho de estar trabajando con precariedad de recursos: «las películas de Ruiz, Francia y Littín fueron realizadas, consecutivamente, con la misma cámara» (King, 1994, p. 242). Otro hecho trascendente, no sólo para el cine nacional sino también para las cinematografías de la región, es el Festival Cine de Viña del Mar del año 1967, junto al que se realizó el Primer Encuentro de Cineastas Latinoamericanos. El gran mérito de dicho festival fue el de generar conciencia entre los cineastas de que en la región se estaba desarrollando una nueva manera de comprender la práctica cinematográfica. Al respecto, Jorge Sanjinés declararía:

Sin conocernos estábamos trabajando en una misma idea, convencidos de un mismo deber. Comprendíamos que cada uno en su propio país, tendría poco tiempo para denunciar la miseria, analizar sus causas, combatir la confusión, informar sobre lo que deliberadamente se oculta al pueblo, exaltar y contribuir a rescatar nuestra personalidad cultural, etcétera, tareas urgentes e indispensables que significaban crear conciencia de liberación (Sanjinés, 1988, p. 100).

Por otra parte, toda esta efervescencia y emergencia de una nueva práctica cinematográfica se ve enmarcada dentro de un contexto sociocultural y político que, en el caso chileno, reviste cierto particularismo. El Gobierno de Eduardo Frei Montalva tenía como eslogan «Revolución en Libertad» y se presentaba como una tercera opción frente al capitalismo norteamericano y al socialismo soviético. Ahora bien, esta «Revolución en Libertad» llevó adelante reformas destinadas a mejorar las condiciones socioeconómicas de la población, sin embargo, estas no afrontaban radicalmente las desigualdades del país. Por ejemplo, la llamada «chilenización» del cobre hizo más favorables las condiciones para las compañías norteamericanos, y la reforma agraria fue muy parcial. En 1969 las expropiaciones sumaban algo más de 1300 predios, equivalentes a casi 3 millones y medio de hectáreas, por lo tanto,

no se logró el objetivo de crear 100 mil nuevos propietarios - de hecho nadie llegó a ser propietario-, la reforma agraria de Frei había beneficiado a casi 30 mil familias organizadas en asentamientos (JocelynHolt, 1999, p. 107).

También hubo algunos tímidos intentos por realizar reformas que promovieran el cine, creándose un consejo para promocionar la industria cinematográfica nacio- 
nal, cuyo mayor logro, en 1967, fue conseguir que los productores locales recibieran un porcentaje de los ingresos de la taquilla. Así, la ayuda del gobierno a la producción cinematográfica chilena es comparable, en términos de resultados, con la «chilenización» del cobre o la reforma agraria, porque lo que se buscó fue realizar una reforma sin afectar los intereses existentes: los latifundios en el agro, las grandes compañías mineras estadounidenses y los distribuidores extranjeros que tenían la hegemonía en la exhibición y distribución de películas en el país.

Ahora bien, una práctica cultural emergente se estructura a partir de una relación, ya sea como alternativa o como oposición con los elementos dominantes. Desde el punto de vista de esta investigación, el nuevo cine chileno emergió, por una parte, como una alternativa a la producción cinematográfica dominante encabezada por Hollywood y la Época de Oro del cine latinoamericano, las cuales eran vistas como imperialistas, burguesas, alienadas y colonialistas. A esto se oponía la dimensión marcadamente política, revolucionaria, progresista y descolonizadora, que participaba activamente en «la vía chilena al socialismo» y que manifestaba por medio de la producción fílmica «la importancia de los valores populares como fuente de reflexión cultural» (Gallardo, 2007, p. 126). De esta forma, los artistas querían transformar el arte en instrumento de acción política.

Al finalizar los 60 ya se comienza a vislumbrar lo que será una marcada tendencia en la películas de principios de los 70, la de utilizar a los obreros (y su entorno social, familiar, etcétera) como el «gran»re- presentante del mundo popular, lo cual resulta un tanto parcial, puesto que los obreros conforman una parte mínima de ese «mundo popular». Asimismo, la identidad de los sujetos populares no se encuentra fijada a un único sujeto, por el contrario, está constantemente reformulándose, resignificándose, desde y sobre las experiencias acumuladas en la base, de las percepciones que las elites tienen de ellos y de las funciones que el Estado, la Iglesia y, más contemporáneamente, los medios de comunicación social les han asignado (Salazar y Pinto, 1999, p. 96).

En esta etapa de consolidación, el nuevo cine chileno ya no sólo busca proyectar en imágenes y sonidos a los sujetos populares desde la tradición de sus prácticas culturales o desde la objetivación en imágenes y sonidos de las problemáticas sociales., económicas y culturales. Ahora también se intenta explicar las causas de dichas problemáticas, denunciar a los agentes causantes de dichas desigualdades y promover la lucha social a través de la enunciación de un discurso audiovisual que persigue producir un acto de subversión del proletariado frente a los poderes hegemónicos, para lograr así revertir las adversas condiciones sociales en que se desenvuelven los sujetos populares. De ahí que, en esta etapa de consolidación, estemos en presencia de una discursividad performativa, entendida esta como la enunciación fílmica que va acompañada de un acto: el de producir «las transformaciones revolucionarias que el país necesita y que sólo podrán realizarse si el pueblo chileno toma en sus manos el poder y lo ejerce real y efectivamente» ${ }^{6}$. 


\section{LOS CINEASTAS Y LA IDEOLOGÍA DE "LA VOZ DE LOS SIN VOZ"}

Durante la década de los 60, Chile experimentó un «estallido» de sus bases populares. Este estallido social, que tenía lugar en gran parte del continente, trajo consigo el reconocimiento de que los sectores populares eran un espacio social en donde se constituían sujetos sociales con demandas, objetivos y reivindicaciones, y que lograban articular movimientos socialespopulares. Dentro de ese contexto social y en conjunto con otras prácticas culturales e intelectuales, los cineastas revindicaron la historicidad de los sujetos populares a través del reconocimiento de «su capacidad para tomar conciencia de las condiciones adversas a las que históricamente han estado sometidos (pobreza, subordinación, exclusión)» (Salazar y Pinto, 1999, p. 99). Sin embargo, es evidente que quienes construyen audiovisualmente lo popular y sus problemáticas sociales son un grupo de individuos pertenecientes a una clase social pequeño burguesa, intelectualizada, de izquierda, que objetiva en imágenes y sonidos lo popular bajo una retórica audiovisual que se instituye bajo la ideología de «la voz de los sin voz».

Estos grupos privilegiados con consciencia social convirtieron lo popular y sus conflictos socioculturales en estandarte de la lucha revolucionaria, de modo que los sujetos populares son inscritos dentro de un proyecto político (el socialismo) el cual los ubica dentro de una clase social (el proletariado). Así, la práctica cinematográfica desarrollada en el país durante los años 60 es un proyecto ideológico, que posee un corpus de películas adscritas a un determinado programa político y estético, que va tener su consolidación con la llegada en 1970 de Unidad Popular a la Moneda.

Ahora bien, las construcciones que se hacen de lo popular por parte del nuevo cine chileno son significantes de un proyecto político mayor, el de la Unidad Popular, y no son ni neutras, ni transparentes, sino por el contrario, están ancladas a un fuerte sustrato ideológico en que los sujetos y sus subjetividades se ven mediatizados por la imagen cinematográfica, que no solamente objetiva en la cinta la imagen visible de lo popular y de ese «hombre nuevo», sino también se configura como un elemento constituyente de las relaciones sociales. De modo que es posible sostener que la práctica cinematográfica desarrollada por los practicantes del Nuevo cine chileno, se configura como un sistema de producción simbólica que encarna una estrategia de poder, que se vincula con el poder simbólico ${ }^{7}$.

Incluso las narraciones más inverosímiles, de alguna u otra manera, ponen en escena a la sociedad que las circunda, haciendo posible identificar a través de una película aquello que una cultura considera visible y aquello que prefiere que permanezca escondido. De modo que tanto aquello que esconde como lo que revela (consciente o inconscientemente) nos permite adentrarnos en el dominio de las ideologías. Ahora bien, que un mensaje mediático sea o no ideológico va a depender de la manera en que sea acogido por los individuos que lo reciben e incorporan dentro de su vida cotidiana. Por ello, cuando entramos en el dominio de las ideologías es necesario enfatizar, por un lado, 
el carácter contextual de la ideología y, por el otro, cómo es construida narrativamente. Esto porque «las ideologías deben su estructura y sus funciones más específicas a las condiciones sociales de su producción y de circulación» (Bourdieu, 2006, p. 70). Por ello, habrá que poner atención en la manera en que las formas simbólicas sirven, en determinadas circunstancias, para establecer y mantener relaciones de dominación.

$\mathrm{Si}$, a primera vista, la ideología de «la voz de los sin voz» pareciera ser una causa noble y llena de buenas intenciones, eso no impide que podamos encontrar inscrito un efecto oculto o connotado. Esto es, una ideología que implícitamente da por sentado que aquellos sujetos excluidos, oprimidos y dominados no van a lograr tener nunca voz propia, puesto que son otros quienes asumen el poder de representarlos, consolidando la hegemonía existente. De ahí que sea pertinente sostener que las representaciones que se hacen de lo popular desde la producción fílmica del período «son, ante todo, una de las apuestas de lucha entre los intelectuales. El de sentirse autorizados para hablar del 'pueblo', o hablar para (en el doble sentido) el 'pueblo'»(Bourdieu, 2000, p. 152). Así, la ideología de «la voz de los sin voz» se constituye como un instrumento de conocimiento y de construcción del mundo objetivo, que cumple la función política de constituirse en instrumento de imposición o legitimación de la dominación de una clase sobre otra, lo que, en última instancia, contribuye a la acumulación de poder simbólico (Bourdieu, 2006). De ahí, que la ideología de «la voz de los sin voz» actúa sobre el registro simbólico creando una construcción que permite hacer ver y ha- cer creer, de confirmar o de transformar la visión del mundo y, por ello, la acción sobre el mundo, contribuyendo así a la domesticación de los dominados.

\section{CONCLUSIONES}

En este trabajo he intentado situar la emergencia de una nueva práctica cinematográfica desarrollada en el país durante la década de los 60. Esta emergió como una práctica cultural que venía a contribuir -junto a otras manifestaciones culturales, políticas, artísticas - a la lucha contra la hegemonía ${ }^{8}$. A través de la filmografía del nuevo cine chileno es posible identificar una nueva concepción cinematográfica, que tanto estética como políticamente, re-significa la cinematografía del país y que se caracteriza por poseer un discurso socialmente pertinente que, tanto la Época de Oro del cine latinoamericano como el cine hollywoodense, excluyen de sus códigos de significación.

Sin embargo, el nuevo cine chileno es una moneda con dos caras que en algunos aspectos se contradicen. Por una parte, podemos encontrar una enunciación que expresa un conjunto de aspiraciones en los órdenes político, cultural, social, artístico e ideológico, logrando conformar una producción simbólica que se establece desde el discurso revolucionario y que busca proyectar una visión de mundo común basada en la cooperación, en la solidaridad, en la participación comunitaria y en la necesidad urgente por encontrar una forma discursiva propia en el plano estético acorde con el ideario político al cual 
adscribían los cineastas. Por otra parte, es posible determinar que las construcciones discursivas acerca de los sujetos populares y sus problemáticas sociales no son separables de las condiciones o reglas de las que, en gran medida, los practicantes del nuevo cine chileno son inconscientes y que, de alguna u otra manera, determinan los trabajos realizados. Esta, como hemos visto, es la ideología de «la voz de los sin voz» que termina por reproducir la hegemonía de una manera inconsciente

Así, lo que se ha perseguido, de manera provisional, es describir la trama de diferentes temporalidades que se influyen, conviven y se inscriben en el desarrollo de la práctica cinematográfica dentro de una formación cultural. Se ha querido dar cuenta de las relaciones dinámicas, cambiantes y contradictorias que se dan en el interior de una misma sociedad, y de cómo la práctica cinematográfica, en cuanto práctica significante, participa en el dinamismo de una cultura donde coexiste una diversidad de elementos dominantes, emergentes y residuales, por lo que difícilmente una formación social puede reducirse a un bloque definido por una sola supremacía histórica o social.

Por otra parte, he intentado problematizar de forma aproximativa la construcción de lo popular realizada por el nuevo cine chileno. Estoy consciente de que existe una serie de dificultades para precisar qué es lo popular, esto porque el término «popular» posee múltiples definiciones, es empleado de diversas maneras $\mathrm{y}$ es indefectiblemente impreciso. Es un término fugitivo, inestable y cargado de normativa. Es un concepto polisémico que hace referencia a un tema colectivo - el pueblo»-, lo cual lo hace sumamente problemático porque, al igual que no encontramos ningún sentido fijo a la categoría de «cultura popular», tampoco hay un sujeto fijo al cual adjudicársela. Partimos de la base de que la cultura popular es el terreno en donde se articulan las transformaciones socioculturales en un sistema capitalista. Este terreno no puede ser considerado como un espacio sosegado, sino por el contrario, es posible pensarlo como un campo de batalla donde el término «popular» tiene relaciones muy complejas con el término «clase»?. Asimismo, el término popular nos remite al campo de los oprimidos, los excluidos, los subordinados. Lo opuesto a lo popular no es una clase entera, sino una alianza: la cultura del bloque de poder, que dispone del poder cultural para decidir aquello que corresponde y lo que no corresponde a las masas o a la elite.

El nuevo cine chileno articuló un discurso fílmico en el cual los sujetos populares eran inscritos, al menos, dentro de dos experiencias que son transversales a la dificultosa noción de popular: la primera es la experiencia de la pobreza. Los sujetos populares son pobres, el pueblo es pobre y esa condición se encuentra como rasgo distintivo de la filmografía del nuevo cine chileno, la cual no solo daba cuenta de una realidad de pobreza de los sujetos populares y su entorno social, sino que a su vez era una cinematografía empobrecida en sus propios medios de producción. La segunda es la experiencia de la dominación: los sujetos populares son sujetos subordinados y el nuevo cine chileno buscó exponer y denunciar, a través de la 
puesta en escena, las distintas formas de subordinación que han afectado al mundo popular.

Por último, en el proceso que va desde la eclosión del nuevo cine chileno hasta su consolidación, podemos apreciar la emergencia de una nueva forma cinematográfica que asumió una postura combativa que se hace cargo de los contextos históricos, sociales y políticos de su emergencia, contri- buyendo al mismo tiempo con un espacio de alteridad y cuestionamiento frente al poder, la dominación y la hegemonía. El nuevo cine chileno se estructura como un proceso que fluctúa a partir de lo emergente, se consolida como dominante durante el gobierno de la Unidad Popular, y se vuelve residual durante los primeros años de la dictadura militar, la cual comienza a instalar un nuevo sujeto popular acorde con la imposición del sistema neoliberal.

\section{NOTAS}

1 Este trabajo se enmarca la investigación acerca del Nuevo Cine Latinoamericano desarrollada para mi tesis de Magíster en Estudios Latinoamericanos.

2 El Hogar de Cristo es una institución de la Iglesia Católica que busca acoger, integrar, y rehabilitar a los más pobres a través de distintas iniciativas.

3 La Época de Oro del Cine Latinoamericano se enmarca entre finales de los años 30 y principios de los 60. Se caracteriza, a grandes rasgos, por la eclosión de algunas cinematografías regionales en industrias cinematográficas - Argentina, Brasil y México -, las cuales exportaban sus producciones al resto de América Latina.

$4 \quad$ El huacho es el hijo que no posee la presencia paterna.

5 Sobre el mestizaje chileno véase Madres y huachos: alegorías del mestizaje chileno. Sonia Montecino 1996, Santiago de Chile, Editorial Sudamericana.

6 Programa básico del Gobierno de la Unidad Popular, 1970.

7 «El poder simbólico es, en efecto, ese poder invisible que no puede ejercerse sino con la complejidad de los que no quieren saber que lo sufren o incluso que lo ejercen» (Bourdieu, 2006, p. 66).

8 Por hegemonía, Gramsci entendía la penetración a través de la sociedad civil -incluyendo una serie completa de estructuras y actividades como los sindicatos, la escuela, la iglesia, la familia, el arte- de todo un sistema de valores, actitudes, creencias, moralidad, etc., que de una u otra manera contribuyen a sostener el orden establecido y los intereses de la clase dominante. 
De la eclosión a la consolidación. Una mirada aproximativa a la construcción de lo popular por el nuevo cine chileno 1958 -1970

9 Es conveniente tener presente que los términos de «clase» y «popular», si bien se encuentran profundamente relacionados, no son intercambiables. Esto se debe a la inexistencia de “'culturas' totalmente separadas que, en una relación de fijeza histórica, estén paradigmáticamente unidas a clases 'enteras' específicas, aunque hay formaciones clasistas-culturales claramente definidas y variables. Las culturas de clase tienden a cruzarse y coincidir en el mismo campo de lucha. El término 'popular' indica esta relación un tanto desplazada entre la cultura y las clases» (Hall, 1984, p. 108).

\section{REFERENCIAS BIBLIOGRÁFICAS}

Alegría, Fernando. 1986. Nueva historia de la novela hispanoamericana. Hanover, New Hampshire: Ediciones del Norte.

Bourdieu, Pierre. 2006. Sobre el poder simbólico. En Intelectuales, política y poder. Buenos Aires: Editorial Universitaria de Buenos Aires, pp. 65-73.

Bourdieu, Pierre. 2000. Los usos del pueblo. En Cosas dichas, Barcelona: Gedisa Editorial, pp. 152-157.

Deleuze, Gilles. 1985. La imagen-tiempo. Estudios sobre cine 2. Barcelona: Paidós.

Foucault, Michel. 1999. Las Mallas del poder. En Estética, ética y hermenéutica. Obras esenciales III. Barcelona: Paidós, pp. 235-254.

Gallardo, Francisco. 2007. A la sombra del sol y la penumbra de los tiempos de la historia. En Estudios Atacameños: Arqueología y Antropología Surandinas No. 33, San Pedro de Atacama, pp. 125- 132 .

Hall, Stuart. 1984. Notas sobre la deconstrucción de lo popular. En Historia popular y teoría socialista. Samuel Ralph (editor) Barcelona: Crítica, pp. 93-109.

Jocelyn-Holt, Alfredo. 1999. El Chile perplejo. Del avanzar sin transar al transar sin parar. Santiago de Chile: Planeta.

King, John. 1994. El carrete mágico: historia del cine latinoamericano. Bogotá: Tercer Mundo Editores.

Muesca, Jacqueline. 1988. Plano secuencia de la memoria de Chile. Madrid: Ediciones del Litoral

Said, Edward. 1990. Orientalismo. Madrid: Librerías / Prodhufi S.A.

Salazar, Gabriel y Julio Pinto. 1999. Historia contemporánea de Chile Vol. 2. Actores, identidad y movimiento. Santiago de Chile: LOM Ediciones. 
Sanjinés, Jorge. 1988 [1969]. Testimonio en Mérida (Venezuela). En Hojas de cine: testimonios y documentales del nuevo Cine Latinoamericano Vol.1, México D.F.: Universidad Autónoma Metropolitana (UNAM), pp.97-101.

Shohat, Ella, y Robert Stam. 2002. Multiculturalismo, cine y medios de comunicación. Barcelona: Paidós.

Vega, Alicia. 2006. Itinerario del documental chilena 1900 1990. Santiago de Chile: Universidad Alberto Hurtado.

Williams, Raymond. 1980. Marxismo y literatura. Barcelona: Ediciones Península. 